\title{
UTILIZING PEER AND TEACHER FEEDBACK IN ACADEMIC WRITING CLASS
}

\author{
Taufiqulloh \\ Department of English Education, Pancasakti university Tegal \\ E-mail: taufiqkayla@gmail.com \\ Yuvita \\ Department of English Education, Pancasakti university Tegal \\ E-mail:yuvieta@rocketmail.com \\ Imam Yuliarto \\ Department of English Education, Pancasakti university Tegal \\ E-mail: imamyuli@yahoo.com
}

APA Citation: Taufiqulloh, Yuvita, \& Yuliarto, I. (2016). Utilizing peer and teacher feedback in academic writing class. English Review, 4(2), 161-170

Received: 10-02-2016

Accepted: 13-03-2016

Published: 01-06-2016

\begin{abstract}
A process approach is usually employed in the classroom instruction of academic writing, particulary essay writing, in the Indonesian colleges or universities. This study investigates the role of teacher and peer feedback inserted in the steps of writing process on students' writing achievement. It is an experimental research conducted at the English Education Department of Pancasakti University Tegal Central Java Indonesia, in the seven semester of the academic year 2015/2016. The participants of this study are 40 students who attended essay writing class. The instrument is essay writing test which was administered before and after treatment to both experimental and control group. By using paired-sample t-test and f-test, it was found that the use of teacher and peer feedback were effective to teach essay writing. Such a technique contributed a significant improvemental to the students writing achievement in the experimental group. The result also showed that the writing achievement of the students in the experimental group was better than that of those in the control group. To conclude, utilizing teacher and peer feedback is considered to be one of the effective ways for the students in learning essay writing. However, some drawbacks were found that need to be taken into account in the next related researches.
\end{abstract}

Keywords: Teacher feedback, peer feedback, essay writing

\section{INTRODUCTION}

In the EFL context of higher education, writing is considered as an important skill since it is not only an object of education, but it is also a skill leading to professional development. Students must produce academic writing works as part of their study. Carolina C, et.al. $(2003$, p. 9) stated that at the university level, disciplinary knowledge, and understanding are largely exhibited and valued through the medium of writing. Students can begin to understand the significance of writing by becoming aware that writing takes particular conventional forms in different contexts. However, it is undeniable that writing is assumed to be the most the difficult skill for learners to master. The complexity lies not only in inventing, expressing, and organizing ideas but also in translating or 
interpreting them into texts which are readable. As Nunan (2003, p. 88)

highlighted that writers typically serve two masters: themselves and their own desires to express an idea or feeling, and readers who need to have ideas in certain ways.

In the process of teaching and learning of academic writing at schools or universities in Indonesia in particular, teacher always plays an important role.

Teachers assign students to write a number of topics and then assess the substantive information contained in the message conveyed, and the mechanics of writing (spelling, capitalization, and punctuation). Teachers typically define the topics for writing, establish the criteria for evaluating the writing and grade the writing themselves. This teacher-centered approach is not surprising given that many teachers have origins in a transmission model of learning and instruction, in which teachers provide the basic knowledge to be imparted to students. The transmission model isolates content areas in teaching and emphasizes mastery of component skills in sequential order. Meanwhile, the current trend of in ELT teaching in international context today focuses on creating competent and autonomous learners (Illes, 2012, p. 506). Therefore, to create such learners, the ELT instruction must be student-centered. Moreover, students should be more facilitated in searching feedback from their peers or teachers.

This study presents peer and teacher feedback as a techique in teaching academic writing, particularly essay, to university students. It is intended to find out whether or not teacher and peer feedback are effective to teach academic writing (essay writing) to the students and to figure out the difference in the writing achievement between the students who are taught using teacher and peer feedback and those who are not.

As we know that the need for designing specific support for student writing processes has received much attention in writing research in ELT today. Two specific support mechanisms that can be used are teacher feedback and peer feedback, which have been studied in different domains and educational levels (i.e., Gielen, Tops, Dochy, Onhema, \& Smeets, 2010).

In writing instruction, feedback is usually given by the teacher when writing process is implemented. Teacher gives comments or suggestions on the students'writing relating to various aspects of writing such as format, mechanics, content, organization, grammar and sentence structures. According to Keh (1990) and Hedgcock and Leftkowitz (1996) cited in Purnawarman (2011, p.21) suggest at least four teacher's roles in providing feedback for students' writing: a reader or respondent, a writing teacher or guide, a grammarian, and an evaluator or judge. In students' writing assessment, teacher feedback gives contributions to evalute students' writing quality. Peterson (2013) states that teacher feedback should be both criterion-based and reader-based. Criterion based feedback indicates how well the writing meets the criteria on scoring guides or rubrics. This feedback refers to features such as the appropriateness of the ideas and information, the level of detail and the chosen point of view. Criterion-based feedback also addresses the clarity of communication through the organization of ideas and use of writing conventions and effective language. This type of feedback is most useful when students have previously been given the 
ENGLISH REVIEW: Journal of English Education Vol. 4, Issue 2, June 2016
ISSN 2301-7554

https://journal.uniku.ac.id/index.php/ERJEE assessment criteria and have a clear understanding of the expectations. Indeed, students gain a deeper understanding of the expectations when they have an opportunity to participate in determining the assessment criteria.

Relating to peer feedback, it is a type of assessment performed by equal status learners. The assessor finds and discussess the strengths of weaknesses of students' writing performance for further improvement. It is done during the process of writing. Peer feedback, when guided by teacher modeling and assessment criteria, is a useful assessment for learning tool that has been shown to support students' writing development and contribute to students' revisions to improve their writing (Boscolo \& Ascorti, 2004; Graham \& Perin, 2007).

There are some beneficials of using peer feedback according to Gielen (2010); firstly, peer feedback can increase the social pressure on students to perform well on an assignment. This way, regardless of the actual output of the peer feedback, a mere announcement that it will take place might suffice to raise performance. Secondly, research in higher education shows that students often perceive peer feedback as more understandable and more useful because fellow students 'are on the same wavelength' (Topping, 2003). A third argument of peer feedback beneficials is that it increases the students' ability to understand feedback. When a learner sees what happens behind the curtains of an assessment and participates in it, learning goals are clarified and internalised. Fourthly, peer feedback is quicker. As teacher feedback often has a considerable delay after the submission of an assignment or test, feedback sometimes is not available until after the curriculum has passed to another topic.
In that case, 'imperfect feedback from a fellow student provided almost immediately may have much more impact than more perfect feedback from a tutor four weeks later' (Gibbs and Simpson, 2004, p. 19). Fifthly, peer feedback can be part of an increase in the frequency or amount of feedback. Gibbs and Simpson (2004) emphasise that only giving feedback at the end of the learning process is not enough to support learning effectively and may provoke frustration in the learner.

Another advantage is the individualisation of feedback. If teachers try to provide more timely and more frequent feedback, they often organise it collectively to make this feasible. Thus, peer feedback on writing develops students' self assessment abilities through providing opportunities to learn and apply scoring criteria. It also provides helpful information to guide revisions that improve students' writing (Peterson, 2013).

To draw the findings of this study, some hyphotheses were made. Hypothesis is a provisional or tentative judgment whether or not a certain technique, method, or model is effective regarding the problem researched. There are two kinds of hypotheses in this research: null hypothesis and alternative hypothesis. Srinagesh (2006, p. 337) stated that in the context of experimental research, the null hypothesis is used when the experimental data (which is represented by a sample) does not necessarily warrant a generalization (which represents the entire population) that an intended improvement in the dependent variable did not occur.

The null hypotheses of this research are formulated in the followings:

$\mathrm{H}_{01}$ Teacher and peer feedback are not effective to teach academic (essay) writing to high achievers 
$\mathrm{H}_{02}$ Teacher and peer feedback are not effective to teach academic (essay) writing to low achievers

$\mathrm{H}_{03}$ There is no significant difference in the writing achievement of the students who are taught using teacher and peer feedback and those who are not.

\section{METHOD}

An experimental research was conducted to test whether or not teacher and peer feedback were effective to teach academic writing to the students, particularly essay writing. It was conducted at the English Department of Pancasakti University Tegal Central Java Indonesia, in the seven semester of the academic year 2015/2015 from March to July 2016. The participants of this study are the fourth semester students of English Education Department who attended academic (essay) writing class. The total number of population is about 40 students from four classes. The population was then identified in terms of two kinds of individual differences: high and low achievers. The identification was conducted through an essay writing test. Regarding the results of identification, 40 students were taken as the participants of this study: 20 students as the experimental group (10 high and 10 low achievers) and 20 students as the control group divided in the same way. The intsrument of this study is an essay writing test. Students were asked to write an essay of about $300-600$ words by choosing one of the suggested topics that interested them. Each essay is scored on the basis of how effectively it communicates a whole message for the stated purpose. It is also considered in terms of five characteristics: format and mechanics, content and organization, word/sentence use, and grammar. And to the test the hypotheses as the findings in this study, t-test and f-test were conducted. Paired sample t-test was intended to examine whether or not teacher and peer feedback were effective to teach essay writing to the students. While f-test was to figure out the difference in the writing achievement of the students who were taught using teacher and peer feedback and those who were not.

\section{RESULTS AND DISCUSSION}

Presented in this part are pretesting analysis, hypothesis testing (findings) and its interpretation. Lavene test was employed to test the homogeneity of the research sample. Using one way ANOVA in SPSS 22, the result of the statistic calculation of the test was figured out in the following table:

Table 1. The result of Homogeneity Test

\begin{tabular}{cccc}
\hline Levene Statistic & df1 & df2 & Sig. \\
\hline 1.819 & 1 & 38 & 0.185 \\
\hline
\end{tabular}

Table 1 shows that the gained coefficient (sig.) correlation is 0.185 . As it is greater than 0.05 , it can be drawn a conclusion that the research sample is homogeneous. Thus, the further analysis (hyphotheses testing) can be carried out. The results of null hypotheseses testing of this small scale research were figured out in the followings: 
ENGLISH REVIEW: Journal of English Education Vol. 4, Issue 2, June 2016
ISSN 2301-7554

https://journal.uniku.ac.id/index.php/ERJEE
1) The first null hypothesis $\left(\mathrm{HO}_{1}\right)$ said that "Teacher and peer feedback are not effective to teach academic (essay) writing to high achievers."

Using SPSS 22, paired sample ttest was utilized to test such a hypothesis. It was conducted by comparing the scores of pre-test and post-test of field independent students taught using self-assessment model. If the significance value (sig.) of the 2tailed test drops below the level of significance 0.05 , the null hypothesis (H0) is rejected. Otherwise, it retains. The results are described in the followings:

Table 2. Paired sample statistics

\begin{tabular}{ccccc}
\hline & Mean & $\mathrm{N}$ & Std. Deviation & Std. Error Mean \\
\hline Post-test & 86.60 & 10 & 1.776 & 0.562 \\
\hline Pre-test & 83.60 & 10 & 2.066 & 0.653 \\
\hline
\end{tabular}

Table 2 describes the statistic summary of the scores of essay writing test of the high achivers before and after treatment. The result shows that there is a difference on the mean scores of two variables. The mean score of post-test (86.60) is greater than that of pre-test (83.60).

Table 3. Paired samples test

\begin{tabular}{|c|c|c|c|c|c|c|c|c|}
\hline & \multicolumn{5}{|c|}{ Paired Differences } & \multirow{3}{*}{$\mathrm{T}$} & \multirow{3}{*}{$\mathrm{df}$} & \multirow{3}{*}{$\begin{array}{l}\text { Sig. (2- } \\
\text { tailed) }\end{array}$} \\
\hline & \multirow[t]{2}{*}{ Mean } & \multirow[t]{2}{*}{$\begin{array}{c}\text { Std. } \\
\text { Deviation }\end{array}$} & \multirow[t]{2}{*}{$\begin{array}{l}\text { Std. } \\
\text { Error } \\
\text { Mean }\end{array}$} & \multicolumn{2}{|c|}{$\begin{array}{l}\text { 95\% Confidence } \\
\text { Interval of the } \\
\text { Difference }\end{array}$} & & & \\
\hline & & & & Lower & Upper & & & \\
\hline $\begin{array}{c}\text { Posttest \& } \\
\text { Pretest }\end{array}$ & 3.000 & 1.333 & 0.422 & 2.046 & 3.954 & 7.115 & 9 & 0.000 \\
\hline
\end{tabular}

Drawn from table 3, with the degree of freedom 9 , the significance value (sig. 2 tailed) is 0.000 which drops far below the significance level 0.05 meaning that there was a difference in essay writing achievement before and after the field-independent students were taught using self-assessment model. Therefore, it can be concluded that the null hypothesis $\left(\mathrm{HO}_{1}\right)$ is rejected: Teacher and peer feedback are not effective to teach academic (essay) writing to high achievers.

2) The second null hypothesis $\left(\mathrm{HO}_{2}\right)$ said that "Teacher and peer feedback are not effective to teach academic (essay) writing to low achievers."

To prove this hypothesis, the same statistics analysis procedure as that of the first hypothesis was also utilized. The results are described in the following tables:

Table 4. Paired sample statistics

\begin{tabular}{ccccc}
\hline & Mean & N & Std. Deviation & Std. Error Mean \\
\hline Post-test & 72.30 & 10 & 3.529 & 1.116 \\
\hline Pre-test & 68.80 & 10 & 3.615 & 1.143 \\
\hline
\end{tabular}


The difference between the mean score of pre-test and post-test of the field dependent students taught using selfassessment model is figured out in the table above. As drawn from the table, the mean score of post-test is greater than that of pre-test $(72.30>68.00)$.

Table 5. Paired sample t-test

\begin{tabular}{|c|c|c|c|c|c|c|c|c|}
\hline & \multicolumn{5}{|c|}{ Paired Differences } & \multirow{3}{*}{$\mathrm{T}$} & \multirow{3}{*}{ df } & \multirow{3}{*}{$\begin{array}{l}\text { Sig. (2- } \\
\text { tailed) }\end{array}$} \\
\hline & \multirow[t]{2}{*}{ Mean } & \multirow[t]{2}{*}{$\begin{array}{c}\text { Std. } \\
\text { Deviation }\end{array}$} & \multirow[t]{2}{*}{$\begin{array}{l}\text { Std. } \\
\text { Error } \\
\text { Mean }\end{array}$} & \multicolumn{2}{|c|}{$\begin{array}{l}\text { 95\% Confidence } \\
\text { Interval of the } \\
\text { Difference }\end{array}$} & & & \\
\hline & & & & Lower & Upper & & & \\
\hline $\begin{array}{c}\text { Posttest \& } \\
\text { Pretest }\end{array}$ & 3,500 & 1.080 & 0.342 & 2.727 & 4.273 & 10.247 & 9 & 0.000 \\
\hline
\end{tabular}

It was found from the table 5 that the significance value (sig. 2 tailed) is 0.000 . Referring to the value, it can be drawn a conclusion that there is a difference between the scores of pre-test and those of post-tests due to the conducted treatment. Thus, the null hypothesis $\left(\mathrm{HO}_{2}\right)$ is rejected: Teacher and peer feedback are not effective to teach academic (essay) writing to low achievers.

3) The last hypothesis $\left(\mathrm{HO}_{3}\right)$ said that "There is no significant difference in the writing achievement of the students who are taught using teacher and peer feedback and those who are not."

To prove this hypothesis, $\mathrm{F}$ test was conducted. If the significance value (sig.) drops below the level of significance 0.05 , the null hypothesis (H0) is rejected. Otherwise, it retains. The results of the statistic calculation using two way ANOVA in SPSS 22 were figured out in the following table:

Table 6. Test between subject-factors (The result of ANOVA)

\begin{tabular}{lccccc}
\hline \multicolumn{7}{c}{ Tests of Between-Subjects Effects } \\
\hline \multicolumn{1}{c}{ Source } & $\begin{array}{c}\text { Type III Sum } \\
\text { of Squares }\end{array}$ & $\mathrm{df}$ & Mean Square & $\mathrm{F}$ & Sig. \\
\hline Corrected Model & $1802.475^{\mathrm{a}}$ & 3 & 600.825 & 63.152 & 0.000 \\
\hline Intercept & 244766.025 & 1 & 244766.025 & 25727.232 & 0.000 \\
\hline Individual Difference & 1729.225 & 1 & 1729.225 & 181.758 & 0.000 \\
\hline Learning Method & 60.025 & 1 & 60.025 & 6.309 & 0.017 \\
\hline $\begin{array}{l}\text { Individual Difference * } \\
\text { Learning Model }\end{array}$ & 13.225 & 1 & 13.225 & 1.390 & 0.246 \\
\hline Error & 342.500 & 36 & 9.514 & & \\
\hline Total & 246911.000 & 40 & & & \\
\hline Corrected Total & 2144.975 & 39 & & & \\
\hline a. R Squared $=.401$ (Adjusted R Squared $=.351)$ & & & & \\
\hline
\end{tabular}

Drawn from table 6, it terms of learning method, it was found that the gained the sig.value is 0.001 . As the value drops below 0.05 , it can be said that there is a significant difference in the writing achievement between between the students who were taught using teacher and peer feedback and those who were not. Thus, the last hypothesis $\left(\mathrm{H}_{3}\right)$ that said "There is no significant difference in the writing achievement of the students who are taught using teacher and 
ENGLISH REVIEW: Journal of English Education Vol. 4, Issue 2, June 2016
ISSN 2301-7554

https://journal.uniku.ac.id/index.php/ERJEE peer feedback and those who are not, " was rejected. Further difference is described in the following table:

Table 7. Estimates (Learning method)

\begin{tabular}{ccrrr}
\hline & & \multicolumn{2}{c}{$95 \%$ Confidence Interval } \\
\hline Learning Method & Mean & Std. Error & Std. Deviation & Std. Error Mean \\
\hline Peer \& Teacher Feedback & 79.450 & 0.690 & 78.051 & 80.849 \\
\hline Non Peer \& Teacher Feedback & 77.000 & 0.690 & 75.601 & 78.399 \\
\hline
\end{tabular}

The table above shows that the mean of students taught using teacher and peer feedback is greater than that of those taught without using the method (79.450>77.000). Thus, it can be said that students taught using teacher and peer feedback received more improvement on their writing ability than those who were not.

From the data analysis described above, it was found that this experimental research has drawn three findngs: teacher and peer feedback were effective to teach the students with high achievement (high achievers), teacher and peer feedback were effective to teach the students with low achievement (low achievers), and there was a difference in the writing achievement between the students taught using teacher and peer feedbak and those who were not. Students who learned to write by gathering feedback from their teacher and peers experienced more improvement in their final achievement. At the beginning of this research, from the result of pre-test, some problems were found in students'essays that were not well formatted, containing innacuracies in the use of mechanical skills of writing, poor in content, unorganized, in errors in grammar and sentence structures. Then, the treatment was conducted for one semester for both experimental and control group. In the experimental group, students learned to write essay by gathering feedback from their teacher and peers which were inserted in the steps of writing process of Oshima and Hogue (2006) that consists of creating, planning, writing the first draft, polishing (revising and editing), and writing the final draft. The use of teacher and peer feedback worked after the students wrote their first draft. This collaborative works contributed significant improvements on the students' essays before they submitted their final copy to the teacher. These can benefit both teacher and students involved in the use of collaborative writing as a learning pedagogy (Cerrato \& Rodriguez, 2002; Onrubia \& Engel, 2009).

Using the checklist of writing dimensions (see appendix), students gathered written feedback from their peers and teacher. They let their peers edit and revise their essays. This activity encouraged the students to get enganged in reflective criticism of other students' products and provide feedback, usually using previously defined criteria in rubrics (Falchikov, 1986; Prins, Sluijsmans, Kirschner, \& Strijbos, 2005). After gathering feedback from their peers, the students submitted their works to the teacher for gathering further feedback using the checklist. Through the instrument, teacher assessed the students' first texts in terms of format, mechanics, content, organization, grammar and sentence structures. This really worked well as the students considered writing teacher has reliable expertise in the classroom as 
Guasch, et.al, (2013) said that teacher feedback acquires special significance for the student due to the teacher's expert status. This is also strengthened by what is stated by Alvarez et. al. (2011), that there is a significant correlation between text improvement and students' discussions about the comments received from the teacher.

At the end of the treatment, it was found that the use of teacher and peer feedback contributed a significant improvement on students' essays that were well formatted and utilized accurate meachanical aspects such as capitalization, punctuation, etc. The essays were also rich of ideas, more interesting to read, and well organized since each of which contained introduction, body and conclusion. In addition to that, few mistakes were found in their essays in the use of grammar and sentence structures.

\section{CONCLUSION}

To conclude, utilizing teacher and peer feedback is considered to be one of the effective ways for the students in learning essay writing. However, some drawbacks were found. Getting involved frequently with others in working on their essays, the students became dependent. This is really in contrast with the current situation that the English language teaching today should lead the students to be more independent. Poor quality of feedback from their peers and the increased workload became crucial problems that need to be considered in the next related researches.

\section{ACKNOWLEDGEMENT}

The authors are the teaching staffs of English Education Department, Pancasakti University Tegal Central Java Indonesia. This research was supported under the funding scheme "Penelitian
Dosen Pemula (PDP)" from the

Directorate of Research, Technology, and Higher Education, Republic of Indonesia.

\section{REFERENCES}

Alvarez, I., Espasa, A., \& Guasch, T. (2011). The Value of Feedback in Improving Collaborative Writing Assignments in an Online Learning Environment. Studies in Higher Education, 37, 387400. doi:10.1080/03075079.2010.510182

Boscolo, P. \& Ascorti, K. (2004). Effects of Collaborative Revision on Children's Ability to Write Understandable Narrative Texts. In L. Allal, L. Chanqouy, \& P. Largy (Eds.), Revision: Cognitive and Instructional Processes (Vol. 13, pp. 157-170). Boston, MA: Kluwer.

Carolina, C., Curry. M. J., Goodman, S., Hewings, Ann., Lilis, T.M., \& Swann, J. (2003). Teaching Academic Writing: A toolkit for Higher Education. London: Routledge

Cerrato, T., \& Rodriguez, H. (2002). Studies of Computer Supported Collaborative Writing Implications for Systems Design. In M. Blay-Fornarino, A. Pinna-Dery, K. Schmidt, \& P. Zaraté (Eds.). Cooperative Systems Design (pp. 139-154). Amsterdam: IOS Press.

Gibbs, G. \& Simpson, C. (2004). Conditions under which Assessment Supports Students' Learning. Learning and Teaching in Higher Education, 1, 3-31.

Gielen, Sarah et al. (2010). A Comparative Study of Peer and Teacher Feedback and of Various Peer Feedback Forms in a Secondary School Writing Curriculum. British Educational Journal, 36,1. Februari 2010: 143-162.

Gielen, S., Tops, L., Dochy, F., Onhema, P., \& Smeets, S. (2010). A Comparative Study of Peer and Teacher Feedback and of Various Peer Feedback Forms in a Secondary Writing Curriculum. British Educational Research Journal, 36, 143-162 doi:10.1080/01411920902894070 
ENGLISH REVIEW: Journal of English Education Vol. 4, Issue 2, June 2016

Graham, S., \& Perin, D. (2007). A metaanalysis of writing instruction for adolescent students. Journal of Educational Psychology, 99, 445-476.

Guasch T., Espasa A., Alvares, I., Kirschner. (2013). Effects of Feedback on Collaborative Writing in an Online Learning Environment. Distance Education. Vol. 34, No. 3, 324-338, http://dx.doi.org/10.1080/01587919.2 013.835772

Illes, E. (2012). Learner autonomy revisited. ELT Journal, 66(4):505-513

Keh, C. L. (1990). Feedback in the writing process: A model and methods for implementation. ELT Journal, 44(4), 294-304.

Nunan, David. (2003). Practical English Language Teaching. New York: The McGraw Hill.

Onrubia, J., \& Engel, A. (2009). Strategies for Collaborative Writing and Phases of Knowledge Construction in CSCL Environments. Computers \& Education, 53, 1256-1265. doi:10.1016/j.compedu.2009.06.008

Onrubia, J., \& Engel, A. (2009). Strategies for Collaborative Writing and Phases of Knowledge Construction in CSCL environments. Computers $\mathcal{E}$ Education,
ISSN 2301-7554

https://journal.uniku.ac.id/index.php/ERJEE

53, 1256-1265.

doi:10.1016/j.compedu.2009.06.008

Oshima A., \& Hogue, A. (2006). Writing Academic English. New York: Longman

Peterson, S. S. (2013). Peer feedback on writing: An assessment for learning. Research for Teacher. University of Toronto.

Prins, F. J., Sluijsmans, D. M. A., Kirschner, P. A., \& Strijbos, J. W. (2005). Formative Peer Assessment in a CSCL Environment: A Case Study. Assessment \& Evaluation in Higher Education, 30, 417-444. doi:10.1080/02602930500099219

Purnawarman, P. (2011). Impact of Teacher Feedback on ESL/EFL Students' Writing: Blackburg VA (Dissertation). November 29,2011

Srinagesh, K. (2006). The Principles of Experimental Research (First Edition). Massachusetts: ButterworthHeinemann

Topping, K. J. (2003). Self- and peer assessment in school and university: reliability, validity and utility, in: M. Segers, F. Dochy \& E. Cascallar (Eds.). Optimizing new modes of assessment: in search of qualities and standards (Dordrecht, Kluwer Academic). 


\section{Appendix: Peer/Teacher Editing Checklist of Writing Dimensions}

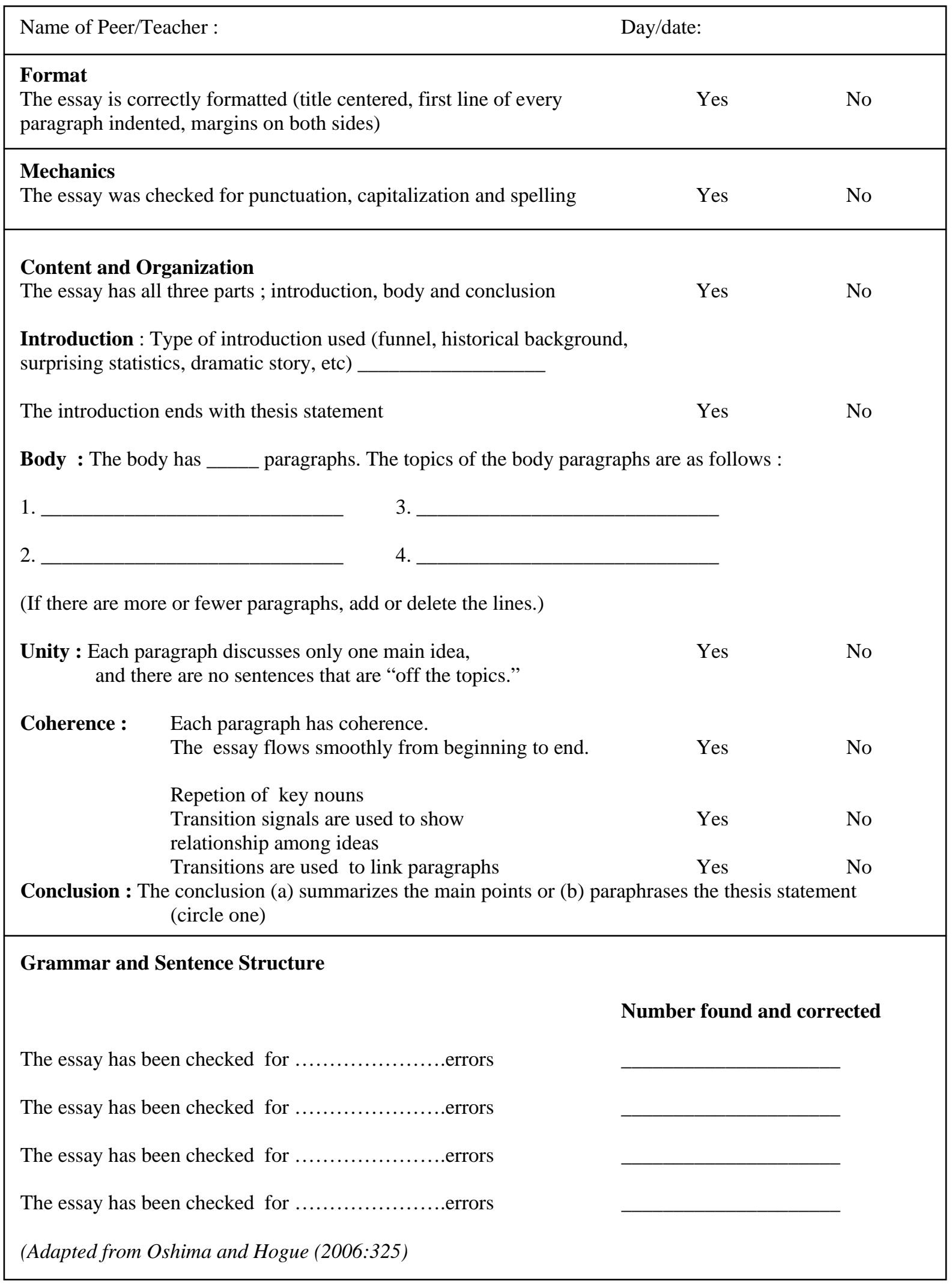

